\title{
Quantification of pancreatic secretory trypsin inhibitor in colonic carcinoma and normal adjacent colonic mucosa
}

\author{
H Bohe, M Bohe, P Jönsson, C Lindström, K Ohlsson
}

\begin{abstract}
Aims: To measure the content of immunoreactive human pancreatic secretory trypsin inhibitor (irPSTI) in colonic carcinoma and adjacent normal colonic mucosa.

Methods: From a stable hybridoma cell line producing monoclonal antibodies specific for human PSTI, a specific enzyme linked immunosorbent assay (ELISA) for human PSTI was developed. In a precipitation assay system these antibodies bound human PSTI in a dosedependent manner. The specimens were obtained from resectional surgery.

Results: The content of irPSTI was $19.9 \mu \mathrm{g} / \mathrm{g}$ protein $(0.55 \mu \mathrm{g} / \mathrm{g}$ tissue wet weight) in colonic carcinoma. In adjacent normal colonic mucosa $43.6 \mu \mathrm{g} / \mathrm{g}$ protein $(1 \cdot 12 \mu \mathrm{g} / \mathrm{g}$ tissue wet weight) was shown. Conclusions: The enzymatic degradation of surrounding tissue necessary for tumour cell invasion could be facilitated by this relative deficit of the inhibitor in infiltrative carcinoma.
\end{abstract}

(F Clin Pathol 1992;45:1066-1069)

Pancreatic secretory trypsin inhibitor (PSTI) was first isolated from pancreatic tissue in 1948 by Kazal. ${ }^{1}$ PSTI is thought to protect the pancreatic gland from damage by preactivated trypsin. The serum concentration of immunoreactive PSTI (irPSTI) is increased in severe diseases such as carcinoma of pancreatic gland, breast, thyroid, stomach, oesophagus, ${ }^{2}$ and gall bladder. $^{3}$

irPSTI has also been shown in and isolated from different parts of the normal gastrointestinal mucosa. ${ }^{4}$ irPSTI has been found in the foveolar cells in the gastric mucosa. In duodenal and small intestinal mucosa irPSTI found in Paneth ${ }^{57}$ and goblet cells. ${ }^{58}$ Normal gall bladder mucosa did not contain irPSTI while well differentiated carcinoma and tissue resembling adenoma did. "

In colonic mucosa ir PSTI has been found in the goblet cells in the basal parts of the crypts. ${ }^{6}$ In colonic adenomas, however, irPSTI was also found in the upper parts of the polyps following the reverse mode of regeneration. ${ }^{12}$ irPSTI has not been shown in most colonic carcinoma tissue. ${ }^{13}$

\section{Methods}

Electrophoresis reagents, dextran T500, protein A sepharose $\mathrm{Cl}-4 \mathrm{~B}$, and $\mathrm{CNBr}$-activated sepharose CI-4B were produced by Pharmacia LKB Biotechnology, Uppsala, Sweden. Class specific goat anti-mouse immunoglobulins were obtained from Nordic Immunologic Laboratories, Tilburg, the Netherlands. Alkaline phosphatase conjugated avidin was obtained from Dakopotts AB, Hägersten, Sweden. Tissue culture medium and fetal calf serum were supplied by Gibco Laboratories, Grand Island, New York, USA. Pansorbin was obtained from Calciobiochem Corporation, San Diego, California, USA. Recombinant PSTI (rPSTI) was obtained from Synergen Inc, Boulder, Colorado, USA. All other chemicals and proteins were purchased from Sigma Chemical Co, St Louis, Missouri, USA.

PRODUCTION OF MONOCLONAL ANTIBODIES

BALB/c mice (Bommice, Bomholtgärd Breeding and Research Center Ltd, Bomholtvej, Denmark) were immunised by a subcutaneous injection of $30 \mu \mathrm{g}$ of rPSTI in complete Freund's adjuvant, repeated five times at three week intervals with $30 \mu \mathrm{g}$ rPSTI in Freund's incomplete adjuvant. Hybridomas were produced by fusion of SP2/0, non-secreting BALB/c myeloma cells with spleen lymphocytes from two out of five immunised mice. $^{1415}$

SELCTION OF ANTIBODY-PRODUCING HYBRIDOMAS Hybridoma culture fluids were tested for antibody using solid phase ELISA technique. Microtitre plates were coated with $50 \mu \mathrm{l}$ of rPSTI, $10 \mu \mathrm{g} / \mathrm{ml}$. Hybridomas producing antibodies specific for PSTI were selected for cloning. The subclass type of the monoclonal antibodies produced was determined by the double immunodiffusion test. ${ }^{16}$ Cells harvested from cultures of hybridomas producing monoclonal antibodies against PSTI were injected intraperitoneally into BALB/c mice treated with Pristane (Aldrich, Beerse, Belgium) for the production of ascites fluid. The ascites fluid was purified by affinity chromatography on a protein A sepharose CI-4B column equilibrated with $1.5 \mathrm{M}$ glycine$\mathrm{NaOH}, 3 \mathrm{M} \mathrm{NaCI}$, at $\mathrm{pH} 8.9$. The column was washed with this buffer after application of the ascites fluid and the IgG was eluted stepwise with $0 \cdot 1 \mathrm{M}$ citric acid- $\mathrm{NaOH}$ at $\mathrm{pH}$ 
6.0, $\mathrm{pH} 5 \cdot 0, \mathrm{pH} 4 \cdot 0$ and $\mathrm{pH} 3 \cdot 0$. IgG1 was eluted at $\mathrm{pH} 6 \cdot 0$. This IgG1 fraction was loaded on a $\mathrm{CNBr}$-activated sepharose $\mathrm{CI}-4 \mathrm{~B}$ column covalently attached with $70 \mathrm{mg}$ rPSTI. Non-specific binding protein was eliminated by rinsing the column with the TRIS- $\mathrm{HCl}$ buffer and specific elution of the PSTI antibodies was accomplished using reversed flow elution with $0 \cdot 1 \mathrm{M}$ glycine $/ \mathrm{HCl}, 3 \mathrm{M} \mathrm{NaCI}$, at $\mathrm{pH} 3 \cdot 0$.

RABBIT ANTISERUM AGAINST HUMAN PSTI

A polyclonal antiserum against human PSTI was obtained by immunising rabbits with a subcutaneous injection of $200 \mu \mathrm{g}$ rPSTI in Freund's complete adjuvant, repeated three times at three week intervals with $200 \mu \mathrm{g}$ rPSTI in Freund's incomplete adjuvant. The production of mono- and polyclonal antibodies was approved by the ethical committee for animal experiments at the University of Lund.

\section{BIOTINYLATION OF RABBIT ANTI-HUMAN PSTI} ANTIBODIES

IgG fractioned rabbit anti-human PSTI antibodies $(5 \mathrm{mg}$ ) obtained after separation on a protein A sepharose CI-4B column, in $1 \mathrm{ml}$ glycine/HCI buffer, were dialysed against $0 \cdot 1 \mathrm{M} \mathrm{NaHCO}_{3}$ overnight at $+2^{\circ} \mathrm{C}$. N-hydroxysuccinimidobiotin $(120 \mu \mathrm{l} \quad 1 \mathrm{mg} / \mathrm{ml})$ in dimethyl sulfoxide was added to the antibody solution and incubated for four hours at room temperature. The biotin labelled antibodies were then dialysed against $0.01 \mathrm{M}$ phosphate buffered saline (PBS), $\mathrm{pH} 7 \cdot 2$, at $+4^{\circ} \mathrm{C}$, overnight.

INDIRECT IMMUNOPRECIPITATION OF PSTI BY MONOCLONAL ANTIBODIES

Human PSTI $(2 \mu \mathrm{g})$ was incubated in a total volume of $100 \mu \mathrm{l}$ with an increasing amount of monoclonal antibody $(2 \mathrm{mg} / \mathrm{ml})$ and bovine serum albumin (to equalise the protein content in each tube $(5 \mu \mathrm{g} / 100 \mu \mathrm{l})$ in $0.05 \mathrm{M}$ TRISHCI buffer, $0.005 \mathrm{M}$ EDTA, at $\mathrm{pH} 7.4$, at room temperature for 30 minutes. The reaction mixture was further incubated at room temperature for 30 minutes after the addition of $10 \mu \mathrm{l}$ of $20 \mu \mathrm{g} / \mathrm{ml}$ rabbit anti-mouse IgG and at $+4^{\circ} \mathrm{C}$ for 30 minutes after the addition of
$60 \mu \mathrm{l}$ of Pansorbin suspension. The immune complexes were precipitated by centrifugation at $+4^{\circ} \mathrm{C}$. The resulting supernatant fluids $(100 \mu \mathrm{l})$ were taken for the measurement of trypsin inhibition after adding $600 \mu 10.05 \mathrm{M}$ TRIS/ $\mathrm{HCl}, \mathrm{CaCl} 0.02 \mathrm{M}, \mathrm{pH} 8 \cdot 2$, and $100 \mu \mathrm{l}$ trypsin $1 \mu \mathrm{g} / \mathrm{ml}$ with $\mathrm{N}$-benzoyl-isoleucine-glutamine-glycine-arginine p-nitro-anilide hydrochloride as a substrate. Absorbance was measured at $405 \mathrm{~nm}$. The control experiments were carried out with normal mouse IgG instead of monoclonal antibody in the initial step of the incubation.

ELISA

Carbonate buffer, pH 9.6 (0.015 $\mathrm{M} \mathrm{Na}_{2} \mathrm{CO}_{3}$ and $0.035 \mathrm{M} \mathrm{NaHCO}_{3}$ ), was used as coating buffer for the monoclonal PSTI antibody. $0.05 \mathrm{M}$ TRIS- $\mathrm{HCl}$ buffer, $\mathrm{pH} 7 \cdot 4$, containing $0.05 \mathrm{M} \mathrm{CaCl}_{2}, 0.5 \mathrm{M} \mathrm{NaCl}$, and $0.2 \%$ bovine serum albumin was used as sample dilution buffer. PBS containing $0.05 \%$ Tween-20, pH $7 \cdot 4$, was used for washing. Between each incubation step the wells were washed five times with PBS-Tween. The wells were coated with $100 \mu \mathrm{l}$ monoclonal PSTI antibody, $15.0 \mathrm{mg} / \mathrm{l}$ for 24 hours at $+4^{\circ} \mathrm{C}$.

Sample buffer $(100 \mu \mathrm{l})$ containing $1 \%$ bovine serum albumin in each well was incubated for at least two hours at room temperature. Then $100 \mu \mathrm{l}$ of diluted sample or standard were applied per well followed by overnight incubation at $+4^{\circ} \mathrm{C}$. The test samples were used in serial dilutions.

The next incubation step involved $100 \mu \mathrm{l}$ of biotin conjugated rabbit-anti-PSTI antibodies $(5 \mathrm{mg} / \mathrm{ml})$, diluted 1 in 600 in the sample buffer, for two hours at room temperature. After washing, alkaline phosphatase conjugated avidin 1 in 1000 was added to the samples. After a final wash $100 \mu$ l of phosphatase substrate in $10 \%$ ethanolamine buffer, $\mathrm{pH}$ 9.8, containing $\mathrm{MgCI}_{2}(10 \mathrm{mmol} / \mathrm{l})$ were applied and incubated at $+25^{\circ} \mathrm{C}$. The plates were then analysed in an automatic Titertek multiscan photometer at $405 \mathrm{~nm}$.

TISSUE SPECIMENS

Specimens were obtained from 12 consecutive patients who had undergone colonic resection because of carcinoma (one patient had two

Contents of irPSTI in normal colonic mucosa and colonic carcinoma

\begin{tabular}{|c|c|c|c|c|}
\hline \multicolumn{2}{|c|}{$\mu g$ irPSTI/g protein } & \multicolumn{2}{|c|}{$\mu g$ irPSTI/g tissue wet weight } & \multirow[b]{2}{*}{ Differentiation of the adenocarcinoma } \\
\hline Normal mucosa & Cancer & Normal mucosa & Cancer & \\
\hline $\begin{array}{l}75 \cdot 5 \\
31 \cdot 5 \\
59 \cdot 0^{\star} \\
59 \cdot 0^{\star} \\
47 \cdot 1 \\
23 \cdot 9 \\
16 \cdot 1 \\
46 \cdot 5 \\
70 \cdot 8 \\
32 \cdot 8 \\
65 \cdot 4 \\
22 \cdot 5 \\
32 \cdot 4\end{array}$ & $\begin{array}{r}22 \cdot 5 \\
15 \cdot 7 \\
14 \cdot 5 \\
11 \cdot 1 \\
7 \cdot 9 \\
12 \cdot 5 \\
14 \cdot 5 \\
24 \cdot 2 \\
25 \cdot 1 \\
29 \cdot 5 \\
41 \cdot 4 \\
7 \cdot 8 \\
31 \cdot 4\end{array}$ & $\begin{array}{l}1 \cdot 79 \\
0.93 \\
1.59^{\star} \\
1.59^{\star} \\
1.19 \\
0.70 \\
0.37 \\
1.25 \\
1.97 \\
0.99 \\
1 \cdot 88 \\
0 \cdot 66 \\
0 \cdot 82\end{array}$ & $\begin{array}{l}0 \cdot 66 \\
0 \cdot 38 \\
0 \cdot 44 \\
0 \cdot 30 \\
0 \cdot 20 \\
0 \cdot 37 \\
0 \cdot 26 \\
0 \cdot 70 \\
0 \cdot 59 \\
0 \cdot 64 \\
1 \cdot 38 \\
0 \cdot 27 \\
0 \cdot 98\end{array}$ & $\begin{array}{l}\text { Well to moderate } \\
\text { Well to moderate, mucus producing } \\
\text { Well to moderate, highly mucus producing } \\
\text { Moderate, mucus producing } \\
\text { Moderate } \\
\text { Moderate, poorly mucus producing } \\
\text { Moderate to poor, poorly mucus producing } \\
\text { Moderate } \\
\text { Moderate, partly mucus producing } \\
\text { Moderate } \\
\text { Moderate to poor, partly mucus producing } \\
\text { Moderate to poor } \\
\text { Partly poor, partly mucus producing }\end{array}$ \\
\hline
\end{tabular}


colonic carcinomas). Clinical examination of the patients preoperatively did not reveal any other serious disease. From each resected colonic specimen one piece was taken from the carcinoma and one piece from the normal mucosa. The specimens were frozen and stored at $-20^{\circ} \mathrm{C}$ for later analysis. The specimens were thawed and homogenised in four parts $0.05 \mathrm{mM}$ acetic acid with aprotinin (Trasylol) $500 \mathrm{KIU} / \mathrm{ml}$. The homogenates were freezethawed five times. The homogenates were centrifuged $15000 \times g$ for 10 minutes. The supernatants were collected. The precipitates were suspended in two parts acetic acid twice and centrifuged after each suspension. The three supernatant fluids were pooled and stored at $-20^{\circ} \mathrm{C}$ until analysed with the above described ELISA and protein concentration by a modification of Lowry's method. ${ }^{17}$

Histological evaluation was done according to WHO tumour classification and grading. ${ }^{18}$

The Wilcoxon matched-pairs signed ranks test was used for statistical analysis.

\section{Results}

The immunoprecipitation of PSTI by monoclonal antibodies showed a dose dependent binding of PSTI to the antibody. In the ELISA the intra-assay variation was $7 \%$ and the interassay variation was $13 \%$. The lower limit of detection was $1 \mu \mathrm{g} / 1$. The same recovery was obtained for PSTI in the tissue samples after dilution as after dilution of pure human PSTI (parallel dilution curves).

The content of irPSTI in the specimens stated as $\mu \mathrm{g} / \mathrm{g}$ protein and $\mu \mathrm{g} / \mathrm{g}$ tissue wet weight is listed in the table. In all patients malignant tissue contained less irPSTI than the normal adjacent mucosa. The median content in carcinoma was $19.9 \mu \mathrm{g} / \mathrm{g}$ protein, range $7.8-41.4(0.55 \mu \mathrm{g} / \mathrm{g}$ tissue wet weight, range $0 \cdot 20-1 \cdot 38)$. The content in normal colonic mucosa was $43.6 \mu \mathrm{g} / \mathrm{g}$ protein, range $16 \cdot 1-75 \cdot 5(1.12 \mu \mathrm{g} / \mathrm{g}$ tissue wet weight, range $0 \cdot 37-1 \cdot 97)$. This difference was significant $(\mathrm{p}<0.01)$.

\section{Discussion}

PSTI isolated from gastric, small intestinal, and colonic mucosa has been shown to be identical with that from pancreatic gland. ${ }^{679}$ In this study a specific monoclonal antibody against human PSTI was produced. With these antibodies an ELISA was developed for human PSTI. Analyses with this method in 12 patients with 13 colonic carcinomas showed that the median content of PSTI was lower in malignant than in normal colonic mucosa. Although there was an overlap in the range of tissue values, we universally found a lower PSTI content in malignant rather than in normal adjacent mucosa. These findings agree with our earlier findings of immunohistochemical staining results on specimens containing normal colonic mucosa, adenomas, and colonic carcinomas. ${ }^{413}$ In those studies irPSTI was shown in the basal parts of the crypts in normal colonic mucosa but rarely in colonic carcinomas. In polyps containing carcinomatous changes without infiltration of the muscularis mucosa, we noticed a shift from a high PSTI content in adenomatous epithelium to the carcinomatous epithelium where irPSTI was absent. ${ }^{13}$ This shift in content of irPSTI is difficult to explain. The apparent lack of the inhibitor could, however, be explained by increased consumption, because there is evidence to suggest that proteinase production is necessary for tumour cell invasion and that this proteolytic reaction takes place close to the tumour cell. ${ }^{1922}$ Recently two tumour associated trypsin(ogen)s were detected in ovarian carcinoma. These proteases were expressed together with tumour associated trypsin inhibitor (TATI). ${ }^{23}$ TATI is probably identical with PSTI. $^{24}$ The explanation of increased consumption also agrees with the recently demonstrated PSTI mRNA in colorectal cancer. $^{25}$ Gastrointestinal PSTI in normal and neoplastic mucosa may provide an important and hitherto unrecognised protective mechanism. Further studies are required to determine factors which control the secretion of gastrointestinal PSTI and its possible role in gastrointestinal mucosa and carcinoma.

This study was supported by the Swedish Cancer Society (Project No 1300-B89(04XA), the Medical Faculty, University of Lund, Albert Pälsson's foundation, Nils and Agnes Nilssons foundation, the foundation of Malmö General Hospital for Cancer and the foundations of the National Swedish Social Welfare Board.

1 Kazal LA, Spicer DS, Brahinsky RA. Isolation of a crystalline trypsin inhibitor-anticoagulant protein from pancreas. F Am Chem Soc 1948;70:3034-40.

2 Matsuda K, Ogawa M, Murata A, Kitahara L, Kosaki G. Elevation of serum immunoreactive pancreatic secretory trypsin inhibitor contents in various malignant diseases Res Commun Chem Pathol Pharmacol 1983;40:301-5.

3 Borgström A, Wehlin L. Correlation between serum concentrations of three sepecific exocrine pancreatic proteins and pancreatic duct morphology at ERCP examinations. Scand $\mathcal{F}$ Gastroenterol 1984;19:220-7.

4 Bohe M, Borgström A, Lindström C, Ohlsson K. Pancreatic endoproteases and pancreatic secretory trypsin inhibitor immunoreactivity in human Paneth cells. $f$ Cell Patho 1986;39:786-93.

5 Bohe M, Lindström CG, Ohlsson K. Varying occurrence of gastroduodenal immunoreactive pancreatic secretory trypsin inhibitor. $\mathcal{f}$ Clin Pathol 1987;40:1345-8.

6 Bohe M, Lindström C, Ohlsson K. Immunoreactive pancreatic secretory trypsin inhibitor in gastrointestinal mucosa. Adv Exp Med Biol 1988;240:101-5.

7 Freeman TC, Playford RJ, Quinn C, Beardshall K, Poulter L, Young J, Calam J. Pancreatic secretory trypsin inhibitor in gastrointestinal mucosa and gastric juice. Gut 1990;31:1318-23.

8 Fukayama M, Hayashi Y, Koike M, Ogawa M, Kosaki G. Immunohistochemical localization of pancreatic secretory trypsin inhibitor in fetal and adult pancreatic and extrapancreatic tissues. $\mathcal{f}$ Histochem Cytochem 1986;34:227-35.

9 Shibata T, Ogawa M, Matsuda K, Miyauchi K, Yamamoto T, Mori T. Purification and characterization of pancreatic secretory trypsin inhibitor in human gastric mucosa. Clin Chim Acta 1986;159:27-36.

10 Shibata T, Ogawa M, Takata N, et al. Distribution of pancreatic secretory trypsin inhibitor in various human tissues and its inactivation in gastric mucosa. Res Comm Chem Pathol Pharmacol 1987;55:243-8.

11 Bohe $\mathrm{H}$, Bohe $M$, Lindström $C$, Ohlsson $\mathrm{K}$. Immunoreactive pancreatic secretory trypsin inhibitor in normal, inflammatory and neoplastic gallbladders. Gastroenterol Ipn 1991;26:95-8.

12 Risio M, Coverlizza S, Ferrari A, Candelaresi GL, Rossini FP. Immunohistochemical study of epithelial cell proliferation in hyperplastic polyps, adenomas, and adenocarcinomas of the 
13 Bohe $\mathrm{H}$, Bohe $\mathrm{M}$, Lindström C, Ohlsson K. Immunohistochemical demonstration of pancreatic secretory trypsin inhibitor in normal and neoplastic colonic mucosa. $\mathcal{F}$ Clin Pathol 1990;43:901-4.

14 Kennett RH, Denis KA, Tung AS, Klinman NR. Hybrid plasmacytoma production: fusions with adult spleen cells, monoclonal spleen fragments, neonatal spleen cell and human spleen cells. Curr Top Microbiol Immunol human spleen

15 Köhler G, Milstein C. Continous cultures of fused cells secreting antibody of predefined specifity. Nature 1975;256:495-7.

16 Ouchterlony Ö. In vitro method for testing the toxinproducing capacity of diphtheria bacteria. Acta Pathol Microbiol Scand 1948;25:186-91.

17 Schacterle GR, Pollack RL. A simplified method for the quantitative assay of small amounts of protein in biologic material. Ann Biochem 1973;51:654-5.

18 Jass JR, Sobin LH, eds. In: Histological typing of intestinal tumours. International histological classification of tumours.
Geneva: World Health Organization, 1989:32-3.

19 Mullins D, Rohrlich S. The role of proteinases in cellular invasiveness. Biochim Biophys Acta 1983;695:177-214.

20 Liotta L, Rao CN, Barsky SH. Tumor invasion and the extracellular matrix. Lab Invest 1983;49:636-49.

21 Sträuli P, Barret AJ, Baici A. In: Stäuli P, ed. Proteinases and tumour invasion. New York: Raven Press, 1980:210.

22 Tryggvason K, Höyhtyä M, Salo T. Proteolytic degradation of extracellular matrix in tumor invasion. Biochim Biophys Acta 1987;907:191-217.

23 Stenman UH. Tumour-associated trypsin inhibitor and tumour-associated trypsin. Scand f Clin Invest 1990;50 tumour-associated tryp
(Suppl 201):93-101.

24 Huhtala ML, Pesonen K, Kalkkinen N, Stenman UH Purification and characterization of a tumour-associated trypsin inhibitor from the urine of a patient with ovarian cancer. F Biol Chem 1982;257:13713-6.

25 Tomita N, Doi S, Higashiyama $M$, et al. Expression of pancreatic secretory trypsin inhibitor gene in human colorectal tumor. Cancer 1990;66:2144-9. 